\title{
Effect of Oxidation on the Formation of Disinfectant By-products of Low Molecular Weight Organic Matter
}

\author{
E. N. Hidayah*†, O. H. Cahyonugroho*, M. Mirwan*, R. B. Pachwarya** and M. K. Asrori*** \\ *Department of Environmental Engineering, University of Pembangunan Nasional Veteran Jawa Timur, \\ Surabaya, Indonesia \\ **Department of Chemistry, MNC, University of Delhi, New Delhi, India \\ ***Department of Environmental Science, University of Pembangunan Nasional Veteran Jawa Timur, \\ Surabaya, Indonesia \\ $†$ Corresponding author: E.N. Hidayah; euisnh.tl@upnjatim.ac.id
}

Nat. Env. \& Poll. Tech.

Website: www.neptjournal.com

Received: 14-09-2020

Revised: $07-12-2020$

Accepted: $12-12-2020$

Key Words:

Organic compounds

Total organic carbon

Oxidation

Disinfection by-products

\begin{abstract}
Some natural organic compounds (NOC) such as aromatic compounds can trigger the formation of disinfection by-products (DBPs). In chlorination (disinfectant) process resultant water quality depletes. Some safe alternative oxidants are needed for cleaning water pollutants. $\mathrm{KMnO}_{4}$ had shown better oxidation results, especially for reducing aromatic and non-aromatic organic compounds present in water. The aim of this study was to analyze the effect of $\mathrm{KMnO}_{4}$ and $\mathrm{Ca}(\mathrm{OCl})_{2}$ oxidants on the concentration of high and low molecular weight organic matter including aromatic compounds in the water sample. In this experiment, artificial organic compounds, namely sinapic acid (high molecular weight aromatic compound) and resorcinol (low molecular weight aromatic compound) were used to identify the characteristic of organic matter under different molecular weights. Sinapic acid and resorcinol were oxidized by using $\mathrm{KMnO}_{4}$ and $\mathrm{Ca}(\mathrm{OCl})_{2}$ with a minimum contact time of 60 minutes. Samples were analyzed for aromatic contents and total organic carbon (TOC) before and after completion of the experiment by using UV-Vis spectrophotometer at $254 \mathrm{~nm}$ wavelength $\left(\mathrm{UV}_{254}\right)$. It has been observed that both oxidants increased TOC concentration. $\mathrm{Ca}(\mathrm{OCl})_{2}$ produces a higher percentage of organic matter degradation by-products (DBPs) such as chloroform $\left(\mathrm{CHCl}_{3}\right)$ a highly toxic compound than $\mathrm{KMnO}_{4}$. Since $\mathrm{Ca}(\mathrm{OCl})_{2}$ has a higher oxidation potential than $\mathrm{KMnO}_{4}$. It has been observed that $\mathrm{KMnO}_{4}$ is a safer oxidant than $\mathrm{Ca}(\mathrm{OCl}) 2$ as potassium permanganate produces less amount of DBPs.
\end{abstract}

\section{INTRODUCTION}

Some natural organic matter $(\mathrm{NOM})$ are present in water bodies in abundant amount. Generally, these organic compounds are a mixture of different kinds of organic matter. These organic compounds commonly originate from animals, plants, microorganisms and other dead biomes, and their degradation or oxidation products (Baghoth 2011). The presence of NOM contaminant in water causes many problems in the treatment processes, such as de-coloration, unpleasant odor removal, corrosion inhibition, coagulation process, oxidation, absorption, adsorption and membrane filtration process, and also on some oxidation of byproducts of disinfectants in water (Edzwald \& Tobiason 2011). Generally, in water treatment processes, the disinfection reaction using chloride containing disinfectants is considered essential. When the NOM polluted water undergoes chlorination, some active chlorine compounds react with NOM to produce chlorinated disinfection by-products some of them are also toxic in nature like the generation of chloroform $\left(\mathrm{CHCl}_{3}\right)$. Some research- ers have determined that higher levels of organic matter in water sources during the disinfection process also increases the number of carcinogenic compounds in the treated water (Bond et al. 2012). According to that information, it is necessary to think about the use of alternative oxidants or materials to eliminate NOM of water, such as $\left(\mathrm{O}_{3}\right)$ ozone, $\mathrm{ClO}_{2}$, and $\mathrm{KMnO}_{4}$ (Hidayah et al. 2017). Such Oxidation treatment improves water quality and reduces biological growth. Based on previous studies, it is stated that organic matter in raw water must be characterized for better understanding and its effects in water treatment (Sillanpaa et al. 2015). Therefore, synthetic organic materials (sinapic acid and resorcinol) is used for the experiment to represent organic matter, because of their similarity and properties to natural organic matter. In addition, of the above reasons, it has been known that the physical and chemical properties of these compounds are of paramount importance for different types of analyses. Therefore, characterization of changing of organic matter was easily identified during the experimental processes (Sillan- 
paa et al. 2015). The synthetic organic materials having low molecular weights were selected for experimental purposes. It is a known fact that organic aromatic substances produce some carcinogenic byproducts when they react with improper oxidants (Bond et al. 2009). Such situation causes other issues in water treatment and byproduct has shown a harmful effect on the health of living things and environment (Hidayah et al. 2017). After going through many previous experimental results related to oxidative degradation of organic compounds and its by-products, this study was aimed to analyze the effect of $\mathrm{KMnO}_{4}$ and $\mathrm{Ca}(\mathrm{OCl})_{2}$ oxidants on the formation of disinfection by-products (DBPs) of sinapic acid and resorcinol under different sets of experimental conditions.

\section{MATERIALS AND METHODS}

Synthetic organic matters i.e. sinapic acid (molecular formula $\mathrm{C}_{11} \mathrm{H}_{12} \mathrm{O}_{5}$, molecular weight $224.21 \mathrm{~g} / \mathrm{mol}$ ) $10 \mathrm{mg} / \mathrm{L}$ and resorcinol (molecular formula $\mathrm{C}_{6} \mathrm{H}_{6} \mathrm{O}_{2}$, molecular weight $110.1 \mathrm{~g} / \mathrm{mol}$ ) $10 \mathrm{mg} / \mathrm{L}$ were used for experimental purposes, as shown in Fig. 1.

Initially, $\mathrm{KMnO}_{4}$ oxidants were selected for experimental purpose, under different amounts of $\mathrm{KMnO}_{4}$ oxidant 0.5; $1 ; 1.5 ; 2 \mathrm{mg} / \mathrm{L}$ and $\mathrm{Ca}(\mathrm{OCl})_{2}$ oxidant $20 ; 30 ; 40 ; 50 \mathrm{mg} / \mathrm{L}$ during experiments. Synthetic organic compounds i.e. sinapic acid and resorcinol have been mixed with oxidants in a batch process pattern, all the samples were stirred for 60 minutes at $90 \mathrm{rpm}$. Periodically samples were taken from experimental setup to determine the concentration of organic

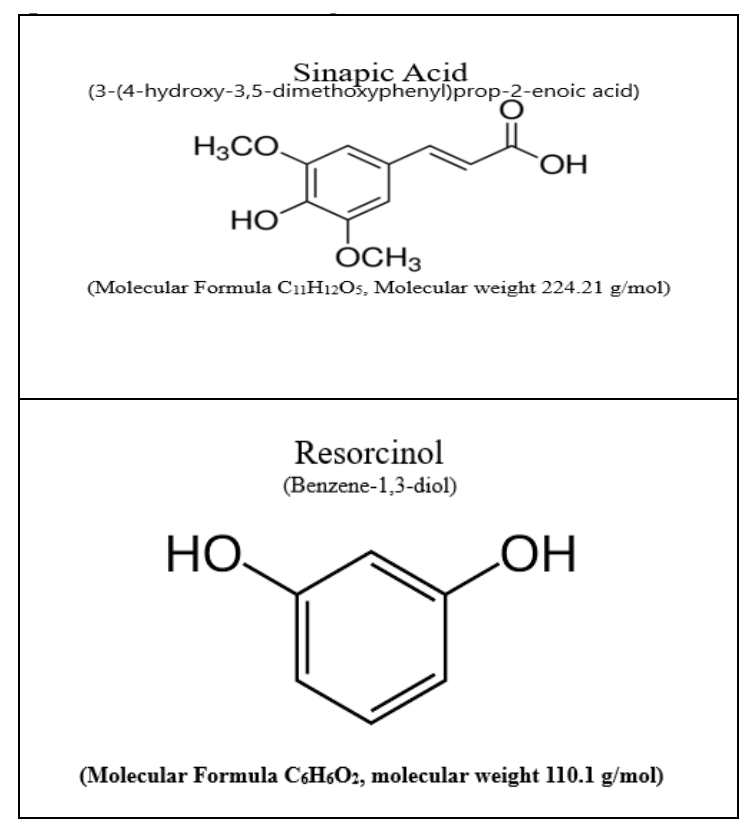

Fig. 1: Molecular formula sinapic acid and resorcinol. matter in terms of TOC by UV-Visible spectrophotometer at $254 \mathrm{~nm}$, and concentration of disinfection by-products i.e. trichloromethanes $\left(\mathrm{CHCl}_{3}\right)$ also known as (THMs). (Hidayah et al. 2018, APHA 2012).

\section{RESULTS AND DISCUSSION}

It is shown in Fig. 2 and Fig. 3, that $0.5 \mathrm{mg} / \mathrm{L}$ amount of $\mathrm{KMnO}_{4}$ oxidant, increased TOC of degradation sample i.e. sinapic acid as the absorbance value decreased to $0.055 \mathrm{~cm}^{-1}$. It indicated that aromatics organic compounds had degraded and non-aromatic compounds were present in more quantity resultant TOC of degradation sample of sinapic acid was incensed. Concentration of TOC in treated sample of resorcinol was increased as the absorbance value decreased to 0.008 $\mathrm{cm}^{-1}$. it indicates that aromatic organic compounds were degraded. It is conjectured that the dominant compounds in resorcinol degradation sample when used $0.5 \mathrm{mg} / \mathrm{L}$ amount of $\mathrm{KMnO}_{4}$ was non aromatic. Furthermore, this study has observed that $1.0 \mathrm{mg} / \mathrm{L}$ amount of $\mathrm{KMnO}_{4}$ for oxidation of sinapic acid shown higher absorbance value and it was increased by $0.271 \mathrm{~cm}^{-1}$. It has been conjectured with more quantity of aromatic compounds in treated sample when TOC was decreased. Meanwhile, this study found that absorbance value for resorcinol was also increased to $0.13 \mathrm{~cm}^{-1}$ when TOC decreased. It indicates the presence of aromatic compounds in treated samples of resorcinol as well as in the sinapic acid. When using $1.5 \mathrm{mg} / \mathrm{L}$ amounts of $\mathrm{KMnO}_{4}$, sinapic acid and resorcinol both have shown a decrease in absorbance values i.e. $0.087 \mathrm{~cm}^{-1}$ and $0.016 \mathrm{~cm}^{-1}$, respectively. This indicates the decrease of aromatic compounds in the treated sample. Lower absorbance UV absorbance at $254 \mathrm{~nm}$ means that after oxidation sinapic acid and resorcinol samples passes non aromatic compounds predominantly. When using $2 \mathrm{mg} / \mathrm{L}$ of $\mathrm{KMnO}_{4}$ oxidant for sinapic acid and resorcinol, the absorbance value of the treated organic material sample was less than the untreated samples, it indicates that TOC increased in the treated samples and non-aromatic compounds were more dominant in the treated samples of sinapic acid and resorcinol then the untreated samples. When using $2 \mathrm{mg} / \mathrm{L}$ amount of permanganate for oxidation of sinapic acid and resorcinol the absorbance value $\left(\mathrm{UV}_{254}\right)$ of the treated organic material sample was less than the untreated samples, indicates more TOC with the domination of non-aromatic compounds in treated samples.

The effect of chlorine oxidant under dosage $20 \mathrm{mg} / \mathrm{L}$ of $\mathrm{Ca}(\mathrm{OCl})_{2}$ for oxidation of sinapic acid indicated an absorption value of treated samples was $0.174 \mathrm{~cm}^{-1}$ less than the untreated samples. In addition, all the samples have been measured for UV-Visible spectrophotometer at 254 $\mathrm{nm}\left(\mathrm{UV}_{254}\right)$. Decrease of absorbance value indicates that 


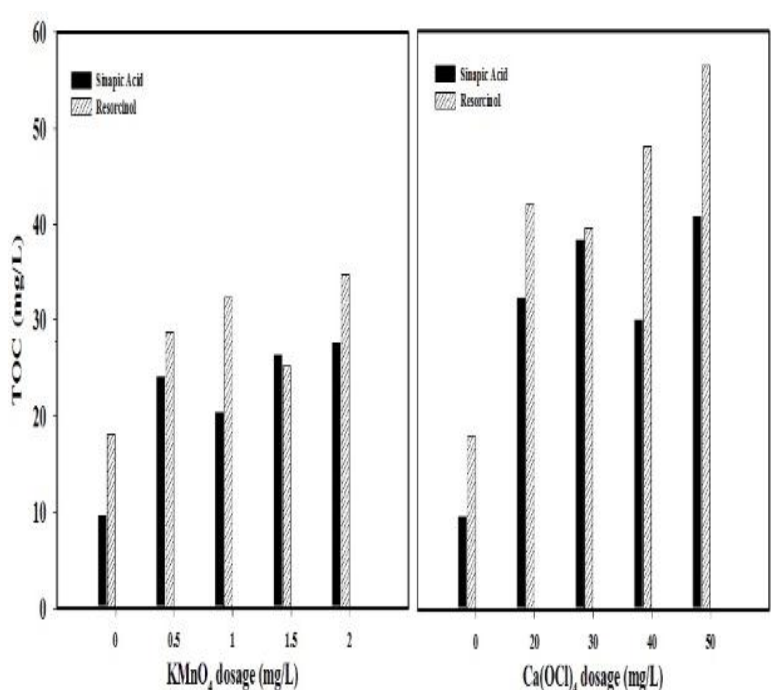

Fig. 2: Concentration of TOC in different low molecular weight under different dosage of oxidants.

aromatic organic compounds are present in less quantity in treated samples as compared to the untreated samples. The results found that TOC increased, it indicates that the non-aromatic organic matter was present in more quantity in treated samples as compared to the untreated samples of sinapic acid.

Meanwhile, this study revealed that the treated sample of resorcinol shows a slight increase in the absorbance value i.e. $0.031 \mathrm{~cm}^{-1}$ higher than the untreated sample. It indicates the presence of aromatic organic matter in domination than the non-aromatic organic matter. This study also found less TOC value (treated sample) which indicates less amount of non-aromatic organic matter in the treated sample. Using $30 \mathrm{mg} / \mathrm{L}$ of $\mathrm{Ca}(\mathrm{OCl})_{2}$ oxidant for sinapic acid, the result showed that TOC value was decreased, which indicates that quantity of non-aromatic matter was less in the treated sample as compared to the untreated sample. This study also observed TOC of the treated sample which was less than the untreated sample has shown that aromatic compounds are more dominant in the treated samples. When using 30 $\mathrm{mg} / \mathrm{L}$ of $\mathrm{Ca}(\mathrm{OCl})_{2}$ oxidant for resorcinol, the absorbance value (UV-254 nm) increased slightly by $0.036 \mathrm{~cm}^{-1}$ which indicates that the dominant compound was aromatic in the treated samples. The TOC value also increased slightly. Next, using $40 \mathrm{mg} / \mathrm{L}$ of $\mathrm{Ca}(\mathrm{OCl})_{2}$ for sinapic acid has indicated of increase in absorbance value to $0.302 \mathrm{~cm}^{-1}$, which means that the increase in organic carbon in with domination of aromatic matter, The increased TOC value also indicate higher organic matter. Using $40 \mathrm{mg} / \mathrm{L}$ of $\mathrm{Ca}(\mathrm{OCl})_{2}$ for resorcinol, the absorbance value increased by $0.069 \mathrm{~cm}^{-1}$, while the TOC value decreased, indicating that the aromatic

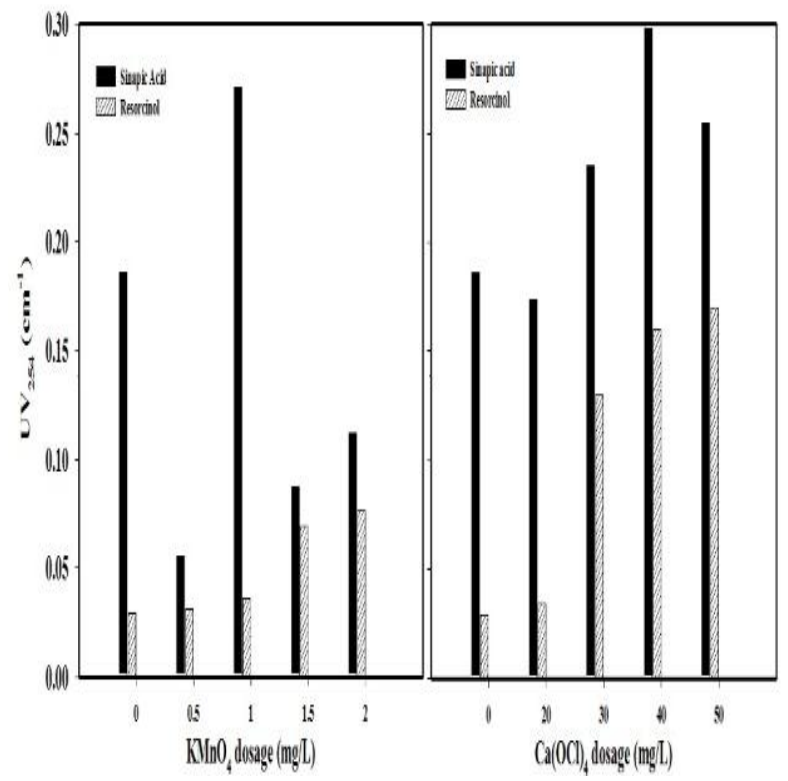

Fig. 3: Concentration of UV254 in different low molecular weight under different dosage of oxidants.

organic matter was dominant than the non-aromatic organic matter. Furthermore, using $50 \mathrm{mg} / \mathrm{L}$ of $\mathrm{Ca}(\mathrm{OCl})_{2}$ oxidant for sinapic acid, it has shown absorbance shifted toward lower value and absorbance decrease by $0.255 \mathrm{~cm}^{-1}$ but the TOC value increased, Both results indicated that the non-aromatic compounds were dominant over aromatic organic matter. TOC also increased due to the conversion of aromatic organic matter into non-aromatic organic matter. Then this study observed the effect of $50 \mathrm{mg} / \mathrm{L}$ of $\mathrm{Ca}(\mathrm{OCl})_{2}$ on resorcinol, the absorbance value UV $254 \mathrm{~nm}$ increased to $0.076 \mathrm{~cm}^{-1}$ and the TOC value also increased, it might be indicated that the aromatic organic matter was in domination over non-aromatic organic compounds. TOC vale also increased indicates that some aromatic organic matter was converted into simpler organic molecules.

Overall, Fig. 2 shows the concentration of TOC for sinapic acid and resorcinol after oxidation under a variation amount of oxidants $\mathrm{KMnO}_{4}$ and $\mathrm{Ca}(\mathrm{OCl})_{2}$. Firstly, the effect of $0.5 \mathrm{mg} / \mathrm{L}$ amount of $\mathrm{KMnO}_{4}$ oxidant on sinapic acid and resorcinol has been observed, and the results showed that both sinapic acid and resorcinol show higher TOC values i.e. $32.4 \mathrm{mg} / \mathrm{L}$ and $42 \mathrm{mg} / \mathrm{L}$ respectively. This study found that increasing the amount of oxidants $\left(\mathrm{KMnO}_{4}\right.$ and $\left.\mathrm{Ca}(\mathrm{OCl})_{2}\right)$, the organic carbon values also increased such as changes in organic carbon value, observed in terms of organic carbon and aromatic organic carbon matter. These changes in higher organic carbon, TOC may be a result of the oxidation process which may have destroyed the organic layer of the surface of particles (Xie et al. 2013, Xie et al. 2016). 
Secondly, this study has observed that TOC of resorcinol oxidation increased slightly higher than the sinapic acid oxidation, whether this study used $\mathrm{KMnO}_{4}$ or $\mathrm{Ca}(\mathrm{OCl})_{2}$ oxidations. From the above observations, it seems that the lower molecular weight of resorcinol may be one reason for its easier oxidation than organic matter having a higher molecular weight (Bond et al. 2012). Lower molecular weight organic matter influences the increase of organic matter. It may be due to an increase in the amount of degraded organic carbon.

Thirdly, $\mathrm{Ca}(\mathrm{OCl})_{2}$ oxidant has a higher concentration of TOC than $\mathrm{KMnO}_{4}$ under different amounts. It is a wellknown fact that both $\mathrm{Ca}(\mathrm{OCl})_{2}$ and $\mathrm{KMnO}_{4}$ are considered strong oxidants. $\mathrm{Ca}(\mathrm{OCl})_{2}$ has a higher reduction potential than $\mathrm{KMnO}_{4}$. Further, it is also found that $\mathrm{Ca}(\mathrm{OCl})_{2}$ oxidized more organic matter into organic by-products. Fig. 3 shows variations in the concentration of aromatic matter (UV-254 $\mathrm{nm}$ absorption) in treated samples of sinapic acid and resorcinol with different amounts of $\mathrm{KMnO}_{4}$ and $\mathrm{Ca}(\mathrm{OCl})_{2}$. It also shows similar changing trends with TOC concentration. Oxidation of aromatic and non-aromatic organic matter is generally a process of breaking down bigger organic molecules into smaller molecules by interaction and /or association with oxidants. The basic principle of oxidation by using $\mathrm{KMnO}_{4}$ is the same as the oxidation process in disinfection. Basically, the oxidation aim was to remove the organic substances from the polluted water whether in pretreatment, or a post-treatment process to reduce the formation of organic by-products (DBPs) (Xie et al. 2016, Edzwald \& Tobiason 2011).

Fig. 4 shows the changes in concentration of trichloromethane or chloroform $\left(\mathrm{CHCl}_{3}\right)$. It has been observed that the concentration of $\mathrm{CHCl}_{3}$ increased with the increased amount of oxidant. Chlorine or $\mathrm{Ca}(\mathrm{OCl})_{2}$ oxidant contributes a higher percentage of chloroform $\left(\mathrm{CHCl}_{3}\right)$ concentration. This study revealed that increasing TOC was in accordance with increasing $\mathrm{CHCl}_{3}$ concentration. These results clearly show that organic matter is a precursor for the formation of the disinfectant by-products (DBPs), in terms of $\mathrm{CHCl}_{3}$ as shown in this study.

This study conjectures that different oxidants have different capacities to oxidize organic matter: to break the organic coating, to degrade aromatic and non-aromatic compounds, to degrade the organic carbon chain, and conversion of other organic matter. Previous studies had shown that increasing TOC concentration is in accordance with increasing $\mathrm{CHCl}_{3}$ concentration (Hidayah et al. 2018). It has been also observed that the addition of chlorine oxidant into the treatment of samples gives a higher concentration of TOC, aromatic organic matter than permanganate, because chlorine has a higher electro volt value i.e. $1.482 \mathrm{~V}$ than permanganate 0.60 $\mathrm{V}$ (Xie et al. 2016). On the basis of different experiments, this study can say that the application of permanganate $\mathrm{KMnO}_{4}$ as an oxidant is safer than chlorine $\mathrm{Ca}(\mathrm{OCl})_{2}$.

\section{CONCLUSION}

This study concludes that $\mathrm{KMnO}_{4}$ as an oxidant is safer than $\mathrm{Ca}(\mathrm{OCl})_{2}$ oxidant. These oxidants are capable to convert aromatic organic compounds such as sinapic acid, resorcinol (experimental compounds), and other organic matter into lower molecular weight organic compounds. Degradation or oxidation of organic matter (aromatic and non-aromatic) was observed in terms of increasing the concentration of TOC. This study found the changing concentration of aromatic compounds, total organic compounds, and the formation of DBPs as indicated by the concentration of chloroform. This study conjectured that different oxidants have different capacities to oxidize organic matter, to break the organic coating, and to degrade aromatic organic molecules, the organic carbon chain. After long observation, this study concluded that permanganate $\left(\mathrm{KMnO}_{4}\right)$ oxidant is a much safer oxidant

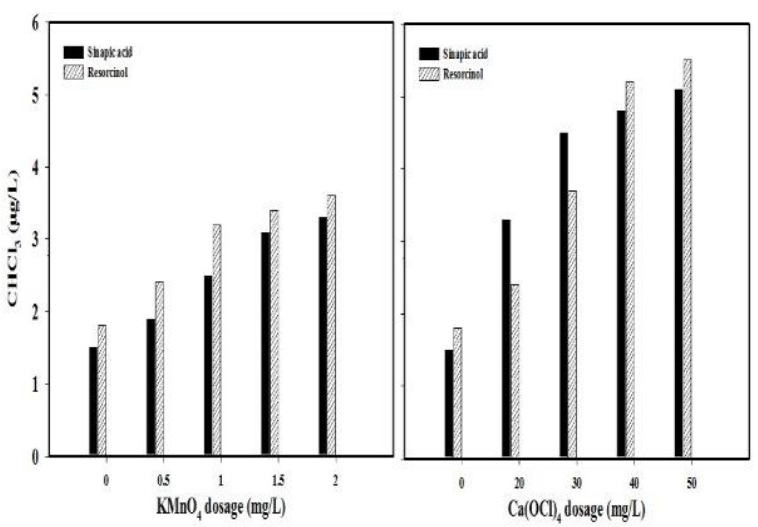

Fig.4: Concentration of $\mathrm{CHCl}_{3}$ in different low molecular weight under different dosage of oxidants. 
than chlorine $\left(\mathrm{Ca}(\mathrm{OCl})_{2}\right) . \mathrm{KMnO}_{4}$ oxidant generates fewer amounts of disinfection by-products such as $\left(\mathrm{CHCl}_{3}\right)$ and many other DBPs.

\section{ACKNOWLEDGEMENT}

This study was a part of funding supported by advanced basic research grants from Research Institutions and Community Service, Universitas Pembangunan Nasional Veteran Jawa Timur. This research accordance with contract no. SPP/90/ UN.63.8/LT/VII/2020.

\section{REFERENCES}

APHA, AWWA, WEF. 2012. Standard Methods for the Examination of Water and Wastewaters, 21th ed., American Public Health Association: Washington, D.C.

Baghoth, S.A., Sharma, S.K. and Amy, G.L. 2011. Tracking natural organic matter (NOM) in a drinking water treatment plant using fluorescence excitation-emission matrices and PARAFAC. Water Research, 45:797-809.

Bond, T., Henriet, O., Goslan, E.H., Parsons, S.A. and Jefferson, B. 2009. Disinfection by-product formation behavior of natural organic matter surrogates. Environmental Science and Technology, 43:5982-5989.
Bond, T., Templeton, M. R. and Graham, N. 2012. Precursors of nitrogenous disinfection by-products in drinking water: a critical review and analysis. Journal of Hazardous Materials, 235-236:1-16.

Edzwald, J.K. and Tobiason, J.E. (ed.) 2011. Chemical Principles, Source Water Composition, and Watershed Protection. In Water Quality \& Treatment: A Handbook on Drinking Water. AWWA McGraw-Hill, New York, pp. 1-76.

Hidayah, E.N., Chou, Y. C., and Yeh, H. H. 2017. Comparison between HPSEC-OCD and F-EEMs for assessing DBPs formation in water. J. Environ. Sci. Health Part A., 52 (4): 391-402.

Hidayah, E.N., Agripina, A.T., Cahyonugroho, O.H. 2018. Effect of preoxidant on the chaning of low molecular weight of natural organic matter, International Seminar of Research Month, Science and Technology for People Empowerment, NST Proceeding, Volume 2018.

Sillanpää, M., Matilainen, A. and Lahtinen, T. (ed.) 2015. Characterization of NOM. In Natural Organic Matter in Water: Characterization and Treatment Method, Butterworth-Heinemann, Oxford, pp. 17-53.

Xie, P., Ma, J., Fang, J., Guan, Y., Yue, S., Li, X. and Chen, L. 2013. Comparison of permanganate preoxidation and preozonation on algae containing water: cell integrity, characteristics, and chlorinated disinfection byproduct formation. Environ. Sci. Technol, 47(24):14051-14061.

Xie, P., Chen, Y., Ma, J., Zhang, X., Zou, J. and Wang Z. 2016. A mini review of peroxidation to improve coagulation. Chemosphere, 155:550-563. 